\title{
Feeling Uncomfortable: Young People's Emotional Responses to Neo-Liberal Explanations for Economic Inequality
}

\author{
by Sarah Smart \\ University of Reading
}

\author{
Sociological Research Online, 17 (3) 1 \\ $<$ http://www.socresonline.org.uk/17/3/1.html> \\ $10.5153 /$ sro. 2560
}

Received: 9 Mar 2011 Accepted: 15 Mar 2012 Published: 31 Aug 2012

\begin{abstract}
People's emotional and political responses to economic inequality are shaped by their beliefs about and interpretations of that inequality. Drawing on a series of group interviews with a total of 11011 - 16 year olds across eight schools I show that participants spoke about economic inequality in terms of rich and poor, but tended to place themselves in the middle of the income distribution. Despite this selfplacement, they often felt very strongly about experiences where economic inequality was visible in consumption patterns. Participants interpreted economic inequality using ideas of neo-liberal meritocracy to explain that the existence of economic inequality was the fair result of different skills or effort among the rich and the poor. But at the same time they used a more egalitarian interpretation to claim that that rich and poor were the 'same kind of people' and that luck played a great part in the different levels of wealth and possessions. This led them to argue that everyone should be treated the same and granted the same respect, regardless of whether they were rich or poor. These egalitarian sentiments were also drawn on to propose strategies to minimise situations where rich and poor might be treated differently, or to manage the difficult feelings and lack of respect that participants associated with situations of economic inequality. These proposals did not challenge the existence of economic inequality, but focussed on the justice of how people with different levels of wealth or possessions should be treated.
\end{abstract}

\section{Keywords: Economic Inequality, Neo-Liberalism, Egalitarianism, Emotions}

\section{Introduction}

$\mathbf{1 . 1}$ In the context of recent growth in the extent and visibility of economic inequality, young people's interpretations of that inequality are both sociologically and politically significant. Over the last fifty years, economic inequality has been growing in the UK (Hills et al. 2010). Since the 1960s and 70s, the ratio between the top and bottom 10\% of incomes has risen from three to more than four, and the top $1 \%$ of income earners now have a 10\% share of the income distribution after tax (a rise from 4.7\% in 1979) (Hills et al. 2010.). In addition, the UK population has become more segregated by income, with poverty becoming more geographically concentrated (Hills 1996). At the same time, individuals have been defined less as producers and more as consumers (Bauman 1998). The subject is understood as autonomous, rational, risk managing, responsible for their own destiny and engaged in 'the reflexive project of the self' (Giddens 1991). As 'entrepreneurs of the self', individual choices about what to consume play a key role in the way people understand themselves and each other (Rose 1996). However, choice and consumption are limited by financial resources. In a context of growing income inequality, those at the top of the income distribution are able to engage in more and more elaborate forms of identity formation through consumption, while those at the bottom have been greatly constrained in their ability to use consumption in identity expression. The highly visible, 'whimsical' nature of consumption among the rich often provokes feelings of stigma, humiliation and insufficiency among the poor (Bauman 1998). Research reveals these kinds of processes occurring in schools where 'brand savvy' young people increasingly use branded clothing, mobile phones, computer games and other leisure accessories to establish their membership of particular style groups (Croghan et al. 2006) and make judgements about others based on what they purchase (Dittmar 1994; Archer et al. 2007). Children and young people from poorer backgrounds find it more difficult to perform certain kinds of style or claim 'trendy' identities and may experience exclusion and abuse as a consequence (Attree 2004; Croghan et al. 2006; Graham 2007; Ridge 2002, 2009). This 'style failure' is often interpreted as an individual moral failure that a young 
person brings upon themselves rather than the consequence of poverty or inequality (Croghan et al. 2006).

1.2 All societies are underpinned by certain values and ideologies which are used to justify how things are or how they should be (Fairclough 2001). These ideologies, whether conscious or unconscious, shape the behaviour of individuals and groups and thereby social structures (Ball 2003; Reay 2007). When people evaluate situations of economic inequality, they draw on normative ideas that are sometimes referred to as theories of justice or theories of social justice (e.g. Rawls 1971). Some theories of social justice also incorporate issues of cultural recognition or political representation (e.g. Fraser 2005; Young 1990). A person's normative beliefs about social justice will influence their evaluation of and response to growth in economic inequality.

$\mathbf{1 . 3}$ In contemporary society, there are conflicting interpretations of economic inequality and social justice. Neo-liberal beliefs that economic inequality is the fair result of differences in the value of people's work are particularly dominant. Neo-liberalism rests on a belief in the primary importance of individual freedom to accumulate capital and is characterised by strong private property rights, free markets and free trade (Harvey 2005). In a neo-liberal framework, economic inequality is understood as the inevitable result of a meritocracy in which individual ability/talent and effort are rewarded (Saunders 2006) and the notion of social justice is either rejected (Flew 1993) or understood as the fair distribution achieved by the free market. Harvey (2005) argues that the values of neo-liberalism have been incorporated into the common sense ways in which many of us interpret, live in and understand the world. Certainly, evidence indicates a general acceptance in the UK that economic inequality provokes hard work and is a necessary precondition of economic growth and success, alongside a belief in the widespread availability of opportunity, a commitment to 'fair inequality' which rewards effort, responsibility and merit, and a tendency to explain poverty or wealth as the result of individual factors (Toynbee and Walker 2008; Bamfield and Horton 2009; Sheldon et al. 2009). However, despite Bauman's suggestion that neo-liberal ideology is hegemonic (Bauman 1999), research does show ways in which people try to draw on other principles in their everyday lives (Ball 2003; Clarke 2004; Riley and Griffin 2007). There are a number of contradictory expressions of social justice (Gewirtz 1998; Sandel 2009). One such theory is the egalitarian idea that economic inequality should exist only as long as it benefits everyone (Rawls 1971). This rests on an assumption about the equal moral worth of all.

1.4 Beliefs about social justice and economic inequality are part of a person's wider framework of moral attitudes and beliefs. Sociologists and social psychologists have long been interested in relative importance of socialisation and cognitive development in the development of these kinds of values. Some argue that children develop moral reasoning in stages, ultimately using higher-level logical reasoning to apply principles and think about what is right or just (e.g. Kohlberg 1983; Avery 1988), while others have shown how interpretations of inequality and beliefs about justice are often taken for granted and are context-dependent (Gorard 2011; Harris 2006; Holland and Thompson 1999).

1.5 Beliefs about social justice and economic inequality are of sociological and political significance, because they shape people's feelings about and reactions to the world around them. They may lead people to support the existing social order, or to protest against or contravene neo-liberal norms (Ball 2003). However, research suggests that people may also hold several different or contradictory beliefs about economic inequality which do not lead them to challenge the status quo (Kleugel and Smith 1986; Orton and Rowlingson 2007).

1.6 Schools are one place where growing economic inequality and young people's developing values collide in interesting and unexpected ways. As already noted, schools are a place where growing economic inequality may be visible in young people's patterns of consumption. English schools have also become increasingly dominated by neo-liberal discourses of competitive, enterprising individualism and meritocracy (Apple 2001). However, schools are also places where young people may have the opportunity to consider other values and ideologies (Apple 1995; Hollingworth 2010).

$\mathbf{1 . 7}$ In this paper I will begin by showing that although young people often talked about economic inequality in terms of the rich and the poor, they did not place themselves in either of these categories. I will discuss how young people used both a neo-liberal meritocratic interpretation of economic inequality, but also a more egalitarian interpretation, showing that the more egalitarian interpretation was used to argue that everyone should be treated the same, while the neo-liberal interpretations were used to defend the continued existence of economic inequality. I will conclude that as long as the ideological conflict between the two interpretations of economic inequality is ignored or minimised, current levels of economic inequality are likely to be maintained. Before reporting my findings, I will set out my methodological approach.

\section{Research Design}

2.1 This paper draws on the focus groups I have conducted as part of a small scale ESRC funded study into pupil constructions of social justice. This study is designed to understand in depth the breadth and variety of meanings and interpretations that pupils use when they speak about inequality and social justice. It has therefore used a qualitative case study approach (Robson 1993; Stake 1995) in eight contrasting schools in the South East of England. These included independent and state schools, mainstream and special needs schools, selective and comprehensive schools, rural and urban schools, single-sex and mixed schools, schools with deprived and affluent intakes and with different patterns of achievement. Achieving this sample was not easy, and for every school that participated, at least one declined to be involved. Details of the schools are given in Table 1. In each school, access to pupils was controlled by a gatekeeper, usually the teacher responsible for citizenship, and was continually negotiated and renegotiated during the course of the research. Teachers were asked to select groups of 
students who got on well together and would engage in discussion, in groups that reflected the academic mix within the school. I interviewed 110 different students between Summer/Autumn 2009 and Autumn 2010. Sixty-nine of these students took part in three focus groups. The majority of students were interviewed in single gender focus groups of between two and seven pupils, but in a few cases were interviewed individually. Students were drawn from two different year groups (aged 11 or aged 14) to give contrasting age perspectives. The total sample was half male and half female. Just over $60 \%$ of the students were White (predominantly White British), almost 20\% Asian (of which half were Pakistani), 3\% Black, $4 \%$ Mixed ethnicity and $13 \%$ did not provide any ethnicity data. In relation to attainment, among the younger pupils, one third came from the top set, one third from other sets, and one third were in schools where there was no setting. The older students were drawn more from those predicted to achieve the highest grades at GCSE, and only $20 \%$ were predicted grades lower than a C, or were not taking GCSEs. I speculated this was because teachers were more reluctant for lower achievers to miss lessons during their GCSE years.

\begin{tabular}{|c|c|c|c|c|}
\hline Name in text & Description & Deprivation & Student body & $\begin{array}{l}\text { Achievement } \\
2009\end{array}$ \\
\hline $\begin{array}{l}\text { Independent } \\
\text { School }\end{array}$ & $\begin{array}{l}\text { Fee-paying } \\
\text { school }(3-18)\end{array}$ & $\begin{array}{l}\text { Located in an } \\
\text { affluent area } \\
\text { with fees in the } \\
\text { region of } £ 5000 \\
\text { perterm }\end{array}$ & $\begin{array}{l}\text { Predominantly } \\
\text { White British } \\
\text { student body } \\
\text { (from } \\
\text { observation) }\end{array}$ & $99 \% 5 A^{*}$ to $C$ \\
\hline $\begin{array}{l}\text { Boy's Grammar } \\
\text { School }\end{array}$ & $\begin{array}{l}\text { Voluntary } \\
\text { controlled } \\
\text { selective boys } \\
\text { school (11-18) }\end{array}$ & $\begin{array}{l}\text { Most students } \\
\text { come from } \\
\text { advantaged } \\
\text { backgrounds } \\
\text { (Ofsted 2007) }\end{array}$ & $\begin{array}{l}\text { One in five } \\
\text { from minority } \\
\text { ethnic } \\
\text { backgrounds } \\
\text { (Ofsted 2007) }\end{array}$ & $\begin{array}{l}100 \% 5 \mathrm{~A}^{*} \text { to } \mathrm{C} \\
\text { (including } \\
\text { English and } \\
\text { Maths) }\end{array}$ \\
\hline
\end{tabular}




\begin{tabular}{|c|c|c|c|c|}
\hline $\begin{array}{l}\text { Girls' Catholic } \\
\text { School }\end{array}$ & $\begin{array}{l}\text { Voluntary aided } \\
\text { comprehensive } \\
\text { school }(11-16)\end{array}$ & $\begin{array}{l}\text { Socially very } \\
\text { mixed (Ofsted } \\
\text { 2008) }\end{array}$ & $\begin{array}{l}\text { High proportion } \\
\text { of students } \\
\text { from minority } \\
\text { ethnic } \\
\text { backgrounds } \\
\text { (Ofsted 2008) }\end{array}$ & $\begin{array}{l}86 \% 5 \mathrm{~A}^{*} \text { to } \mathrm{C} \\
\text { (including } \\
\text { English and } \\
\text { Maths) }\end{array}$ \\
\hline $\begin{array}{l}\text { Comprehensive } \\
\text { School }\end{array}$ & $\begin{array}{l}\text { Community } \\
\text { secondary (11- } \\
\text { 18) }\end{array}$ & $\begin{array}{l}\text { Proportion of } \\
\text { students } \\
\text { eligible for free } \\
\text { school meals is } \\
\text { just above that } \\
\text { usually found } \\
\text { (13\%) (Ofsted } \\
2008)\end{array}$ & $\begin{array}{l}\text { Majority of } \\
\text { students from } \\
\text { White British } \\
\text { backgrounds } \\
\text { (Ofsted 2008) }\end{array}$ & $\begin{array}{l}41 \% 5 \mathrm{~A}^{*} \text { to } \mathrm{C} \\
\text { (including } \\
\text { English and } \\
\text { Maths) }\end{array}$ \\
\hline Pilot school & $\begin{array}{l}\text { Modern (non- } \\
\text { selective) } \\
\text { foundation } \\
\text { school (11-18) }\end{array}$ & $\begin{array}{l}18 \% \text { eligible for } \\
\text { free school } \\
\text { meals (School } \\
\text { profile 2008) }\end{array}$ & $\begin{array}{l}60 \% \text { White } \\
\text { British, } 40 \% \\
\text { Asian British } \\
\text { (School profile } \\
2008 \text { ) }\end{array}$ & $\begin{array}{l}37 \% 5 \mathrm{~A}^{*} \text { to } \mathrm{C} \\
\text { (including } \\
\text { English and } \\
\text { Maths) }\end{array}$ \\
\hline
\end{tabular}




\begin{tabular}{|c|c|c|c|c|}
\hline $\begin{array}{l}\text { Secondary } \\
\text { Modern }\end{array}$ & $\begin{array}{l}\text { Modern (non- } \\
\text { selective) } \\
\text { community } \\
\text { school(11-18) }\end{array}$ & $\begin{array}{l}\text { A high } \\
\text { proportion of } \\
\text { students are } \\
\text { eligible for free } \\
\text { school meals } \\
\text { (Ofsted 2008) }\end{array}$ & $\begin{array}{l}75 \% \text { from } \\
\text { minority ethnic } \\
\text { groups, } \\
\text { predominantly } \\
\text { Pakistanior } \\
\text { Indian } \\
\text { background } \\
\text { (Ofsted 2008) }\end{array}$ & $\begin{array}{l}26 \% 5 \mathrm{~A}^{*} \text { to } \mathrm{C} \\
\text { (including } \\
\text { English and } \\
\text { Maths) }\end{array}$ \\
\hline $\begin{array}{l}\text { Boys' Special } \\
\text { School }\end{array}$ & $\begin{array}{l}\text { Day/boarding } \\
\text { schoolfor boys } \\
\text { with } \\
\text { behavioural, } \\
\text { emotional and } \\
\text { social } \\
\text { difficulties }\end{array}$ & $\begin{array}{l}\text { No information } \\
\text { available }\end{array}$ & $\begin{array}{l}\text { Nearly all of the } \\
\text { students are } \\
\text { White British } \\
\text { (Ofsted 2009) }\end{array}$ & N/A \\
\hline $\begin{array}{l}\text { Girls' Special } \\
\text { School }\end{array}$ & $\begin{array}{l}\text { Community } \\
\text { Special School, } \\
\text { day and weekly } \\
\text { boarding for girls } \\
\text { with moderate } \\
\text { learning } \\
\text { difficulties and } \\
\text { other needs }\end{array}$ & $\begin{array}{l}\text { Pupils come } \\
\text { from very } \\
\text { mixed } \\
\text { backgrounds } \\
\text { (Ofsted 2009) }\end{array}$ & $\begin{array}{l}\text { No information } \\
\text { available }\end{array}$ & N/A \\
\hline
\end{tabular}

2.2 The research received approval from the ethics committee at my institution. A number of ethical issues arose during the design and conduct of the research, especially issues of power and difference within the focus group, and I tried to negotiate these with due regard for minimising harm and participants' right to express their opinions.

2.3 The focus of my research is pupils' constructions of social justice, and the interviews have approached this in different ways: in the first round of interviews I asked the students to talk about things 
they thought were fair and unfair about school; in the second I used a number of prompts from the media to ask students what examples they saw of fairness and unfairness in the world around them; and in the final interview I asked them to describe themselves and any particular interests in fairness or justice. The research was on the different ways in which participants made judgements about fairness, and the questions made reference to working class, middle class and upper class, to parents with professional jobs and parents with manual jobs, and to richer and poorer families. As I was more interested in the process by which participants made fairness judgements, these questions may have encouraged a rather polarized way of talking about inequality. However, as I will go on to show, although participants talked about others in these polarized ways, they did not tend to use these categories to describe their own situations.

2.4 All interviews have been fully transcribed and anonymised, but in this article some quotations have been edited for clarity. Pseudonyms are those chosen by pupils. Where possible I have worked out who said what, but this has not always been possible, so speech is sometimes reported as boy or girl. Transcripts were entered into Nvivo, and coded according to the initial research questions about the principles of justice used by pupils. During the coding process, I became interested in the intensity of the feelings expressed by pupils about economic inequality, and began to look for links between these emotions and the principles of justice used.

\section{Findings}

\section{Young people's descriptions and experiences of economic inequality}

3.1 Young people's discussions of economic inequality were often discussions of rich and poor (a tendency that may have been encouraged by my questions, as I noted earlier). However, they did not tend to describe themselves as either rich or poor, but as 'ordinary' or 'in the middle'.

3.2 Participants used the terms rich and poor extensively. Even conversations that began with questions about class or occupation often turned into discussions about rich and poor. When asked who they thought was poor, participants most often talked about the homeless or people in developing countries. They also suggested that being poor meant not being able to purchase what you wanted. Participants associated being poor with negative social consequences: being called a 'skank', being looked down upon or disrespected. When describing the wealthy, participants also referred to the possessions a person had, with Ben (14 year old boy, Comprehensive School) suggesting that being rich meant 'Having loads of money, having nice cars, living in a nice house, having nice posh stuff,' and 'you can get what you want and not have to pay for it yourself, just ask for it and you get it.' Participants often suggested that rich people were also posh, stuck up and looked down on people.

3.3 While participants used the terms rich and poor to speak about others, they were all reluctant to identify themselves as rich and poor, and suggested that they were in the middle of the income distribution. Only three participants said that they were either rich or poor, most (more than three-quarters) said their household income was either average or slightly above average, and those who described themselves as working class or middle class were usually claiming that they were economically 'in the middle' or 'like everyone else' because their families had to work to survive.

3.4 However, it was clear that different participants meant very different things by 'average' income or being 'in the middle'. For example, Kylie (11 year old boy, Grammar School) said that his household income was well below average, although he wrote that his dad worked full time as an accountant and his mum worked full time as a tutor and teacher. The other members of his group told him that they thought he was rich, which he denied, suggesting that a rich person would have 'a TV in every room and stuff like that, like 3 cars' and he therefore was not rich because his family only had two cars and six TVs. In contrast, Bart P (11 year old boy, Pilot School) said that his household income was well above average. Bart $P$ also told me that he lived in a terraced house and that the only family employment was as a full time shop assistant. It seems likely to me that Kylie's total family income was considerably more than Bart P's, but in their different contexts, they assessed their situations very differently (see Runciman 1966 and Pahl et al. 2007 for similar findings). Another participant at the Independent School objected when the other group members suggested her family income was well above average, protesting that her father was retired. The other girls pointed out that he had retired from a sixteen-year career in professional football where he had played for several well-known Premiership clubs and still worked occasionally as a TV and radio pundit, and therefore earned more than many people, although she continued to assert that her family income was only slightly above average.

3.5 Thus participants talked extensively about observing income inequality between the rich and the poor, but tended to place themselves in the middle of the income distribution, despite coming from a very wide range of different economic situations.

3.6 Although almost all participants described themselves as being economically in the middle or ordinary, they were very sensitive to situations where they felt they had fewer possessions than others. Some highly emotional descriptions were given of the feelings and situations that arose when economic inequality was visible in consumption patterns. Eleven-year old participants at all of the schools commented on this. Students said that, 'On non-uniform day, people who are not wearing labelled stuff get picked on about not having the latest' (Freddy, 11 year old boy, Comprehensive School), 'They say my uncle's got a Porsche or a Ferrari and they go to other people, "Your family is not rich" and say "I've got all the designer clothes and stuff"' (Bart, 11 year old boy, Pilot School), and 'if they can afford a better one, they will just, in a friendly way, take the mickey out of you' (Fitzpatrick, 11 year old boy, Independent School). The 11 year old boys spent longer discussing these kinds of incidents than any other 
participants, particularly in the three schools in the more deprived areas. Although the boys at the Independent and Grammar School acknowledged bullying of those with less desirable possessions, they gave fewer examples and spoke less passionately. Those who had experienced teasing because they didn't have 'the right stuff' spoke about shame and anger. Posh Spice (an 11 year old girl, Catholic School) explained that if someone kept on about how much money they had, people would feel uncomfortable, as if they weren't up to standards. Bonzo (11 year old boy, Special School) admitted that if someone was gloating about their stuff, he would start to invent stories about what he had to make the person feel jealous of him. Leangel (11 year old girl, Secondary Modern School) said angrily 'Shame, that's what I say!' after relating the story of a friend who came into some money and demanded more respect from her.

3.7 Some participants described feeling uncomfortable or jealous about others having more than them even if the other person did not brag.

John It makes the person who doesn't have much .... it might make them feel quite like ... I'm not sure how to put it

\author{
Myles Inferior \\ Bart Yeah, like quite.. \\ John They might feel quite uncomfortable. \\ Sarah So you think rich people might find it easier to be friends with each other? \\ Bart And like, say if you are poor and you are hanging round the rich person and the rich \\ person feels big and you will feel smaller than the rest. (11 year old boys, Pilot School)
}

3.8 Here we see the boys struggling to express feelings of discomfort, unease and inferiority that might arise between two people with different kinds of material possession. As Bart puts it, the richer person might 'feel big' while the other 'feels small,' which could make it hard to get on together. Similarly, a group of 11 year old boys at the Secondary Modern school admitted to feeling jealous of people who always had a new phone, partly because this meant that they would be popular with other students and have lots of friends. They claimed that boys didn't want to 'hang around with the poor people' and so richer boys would 'buy friends' by having the latest games console or a new phone. Several boys suggested that the feelings of jealousy this would provoke might be strong enough to lead a person to steal possessions. Jazz, a 14 year old girl at the Special School, also thought these feelings were serious. She suggested that talking about rich people having 'nice stuff' and poor people having 'really horrible stuff' is 'quite sensitive for some people' and might be linked to instances of self-harm.

3.9 Some participants from all schools related incidents where they had felt uncomfortable that they had more than some people. While incidents of feeling shame or anger for having fewer/inferior possessions involved friends or peers, incidents of discomfort for having more related to people they did not know, like the homeless or people in other countries. For example Shawn (11 year old boy, Comprehensive School) said that seeing poor people on the television made people 'that earn a lot of money and have a really nice job and home [and] feel good about themselves, feel bad.' Several of the groups of girls spoke particularly about feeling guilty or very sad because the homeless or people in other countries had so much less, although no similar emotions were related in relation to other students in the UK. Sometimes other students with fewer/inferior possessions were spoken about dismissively, particularly by participants at the schools in more prosperous locations. These students knew that they were wealthier than some other people their age, and that some regarded them as posh or snobby. While this irritated them, they did not say they felt uncomfortable or awkward. Instead they shrugged it off as 'not important' or dismissed as 'just jealousy' on the part of other students. These discussions were much lighter in tone and the emotions expressed much less strong compared to the discussions about students with more or better 'stuff'.

3.10 Consistent with the shift in constructing identity as a consumer rather than a producer (Bauman 1998), these young people saw consumption, particularly of branded clothing or consumer electronics, as a way 'to be up to standard' and to 'feel big'. Despite their assertions that they were economically 'in the middle' and 'ordinary', they were keenly aware of situations where they did not have the 'right stuff', and spoke about feelings of discomfort, inferiority, and jealousy towards those who had the kind of material possessions they wanted. Sometimes their awareness of having more than the homeless or people in the developing world made them feel uncomfortable or guilty, but other English young people with fewer/inferior possessions were dismissed as 'not important' or 'just jealous'. In the next section I want to consider how these responses to situations of economic inequality might be connected to young people's beliefs about that inequality.

\title{
Beliefs about economic inequality
}

3.11 Participants drew on both neo-liberal, meritocratic interpretations of situations of economic inequality and also more egalitarian interpretations. I will take the two in turn.

3.12 Participants drew on neo-liberal ideas of individualistic meritocracy to explain that the existence of economic inequality was fair. Bonzo (11 year old boy, Special School) told me that it wasn't fair for people to gloat about having more than him, and this made him very angry. But when I asked him whether he thought it was fair for those people to have 'lots more stuff' than him, he told me that it was, as illustrated 
Sarah Do you think it's fair if someone has got lots more stuff than you?

Bonzo Yeah, because if your family hasn't done much work then it's fair that someone else has got more stuff than you, because they might have, their family might have worked for, like, more people innit? And then your family could have just quit, full stop. It's better that someone has more than you. (11 year old boy, Special School)

3.13 Bonzo suggests if someone has more than you because their family has worked harder, this is both fair and desirable. In all groups there was a presumption that the rich 'have obviously worked hard at some point to get there' (14 year old boy) or had 'earned their way up' (Margaret, 14 year old boy, Comprehensive School), and so it was fair that they had the money they did. Azza (14 year old boy, Special School) said that the working class and middle class had 'actually worked to get where they are' which made it 'quite fair'. In many groups there was also the corresponding assumption that the poor were responsible for their position. Dave (14 year old boy, Secondary Modern School) said 'Some people have choices and they make the bad ones and that's why they get poor. It's true, ' while Bill (14 year old boy, Comprehensive School) said 'If they are poor, they are probably poor for a reason.' Jimbo (11 year old boy, Independent School) claimed that someone was at fault if they were poor because they hadn't studied hard enough, and a 14 year old girl at the Comprehensive School argued that poor people had a choice about whether to work hard and become rich or whether to accept that they lived in a poor area. Participants also claimed that hard work was the best way to reduce economic inequality. As Kylie (11 year old boy, Grammar School) explained: 'You could do something about being rich and poor, work really hard to the best of your ability, you could like maybe turn that upside-down,' and Lucas (14 year old boy, Comprehensive School) suggested 'It's up to the poor people to sort it out themselves.'

3.14 These kinds of interpretations of economic inequality were sometimes associated with a sense that those with plenty of possessions did not need to feel awkward about what they had, but were right to be dismissive of the jealousy of others. Thus Pavvi could tell his friend, Superman (both 11 year old boys at the Secondary Modern School), that if people had worked hard and deserved their money, it might be OK to 'flash money around.' Rich people would be entitled to 'feel they are better than others because they have more money' (Posh Spice, 11 year old girl, Catholic School) and to dismiss the envy of those with less as 'just jealousy' and 'not important'. Equally, these interpretations led some participants to conclude that people with fewer/inferior possessions should feel inferior or shamed because 'it's their fault in some kind of way' (Bob, 14 year old boy, Comprehensive School).

3.15 Thus, reflecting dominant neo-liberal evaluations of economic inequality, participants tended to accept the existence of economic inequality as the fair result of differences between people in ability and effort.

3.16 However, many of the young people felt uncomfortable about some of the conclusions associated with the neo-liberal interpretation of economic inequality. In particular, most were very concerned about the way in which rich and poor people might be treated differently. Participants believed this kind of discrimination between rich and poor was widespread in school and in society more generally, from teachers, students and potential employers. When talking about these situations, participants stressed the importance of everyone being treated the same, protesting that that 'we are all the same' and that differences in wealth could be due to luck or good fortune. Participants said things like: 'They [a richer person] are not more special, we are not actually different people, we are the same kind of people' (Violet, 11 year old girl, Special School) and 'it doesn't matter whether they are poor or rich, whether they have an accent or not, everyone is just the same' (Freddy, 11 year old boy, Comprehensive School). This was supported by assertions such as 'You can't treat the rich people different to the poor people because it ain't their fault they ain't as rich as them' (Lampard, 11 year old boy, Secondary Modern School) and '[rich people have to realise] that they are equals ... money is not really a thing that separates them and they are lucky and some people aren't that lucky in life' (Chloe M, 14 year old girl, Secondary Modern School). In a conversation between Suzan, Willy, Lilly and Petal (11 year old girls at the Pilot School), the girls became very angry about richer peers looking down on them 'like a piece of crap.' The girls justified their anger by drawing on the egalitarian statement 'every person is the same'. They argued that because 'we are all human blooming beings', no-one should have any reason to look down on others, boast or brag. These statements challenge the neo-liberal assumption of personal responsibility for wealth and possessions by highlighting the similarities between people and the role of luck in achieving wealth. These interpretations of economic inequality tended to be associated with feelings of anger and jealousy. Taking this line of reasoning to its logical conclusion, these feelings might be understood as 'righteous anger' and their jealousy could be understood as an expression of 'excusable envy' or 'justified resentment' (Ahier and Beck 2003). Similarly, participants' feelings of guilt or sadness at those with less would be the justified response to seeing those who are 'the same' but whose bad fortune meant they had fewer possessions. However, this anger was not usually directed against the existence of economic inequality, but against differential treatment of rich and poor.

3.17 Thus the vast majority of participants drew on both the neo-liberal and egalitarian explanations during the course of the interviews, revealing a striking amount of consistency among participants from all kinds of backgrounds. Even participants from families in very difficult economic circumstances or in very low paid jobs who might have been expected to protest against the implication that their difficult circumstances were the result of laziness or a lack of hard work expressed support for neo-liberal explanations of inequality. For example, Bonzo (11 year old boy, Special School) who explained that his step-dad had recently had a breakdown and so wasn't working, and his mum was looking after his new baby sister, so he couldn't have anything new, but had to 'wait for a bit so it comes down in price,' still asserted that differences between the working class and middle class weren't important, and economic 
inequality was a good thing because it motivated people to work hard. To some extent, this acceptance of the neo-liberal ideology seems to have been linked to their self-assessment of their economic position as normal, ordinary and in the middle.

3.18 While the egalitarian interpretation of economic inequality potentially challenges some of the assumptions at the heart of neo-liberal explanations of economic inequality, in practice participants did not reflect on the conflicts between the two ideologies. Rather egalitarian ideas were used to argue that everyone should be treated the same, while neo-liberal values were used to defend the existence of economic inequality. The exchange below between a group of 14 year old boys at the Comprehensive School illustrates this:

\section{Lucas Everyone should be equal.}

Margaret Everyone should be equal.

Emile Everyone should be treated as equal, but they aren't all equal because of the way they act in life, I think.

Bob Yeah, because some people choose to live that lifestyle, as a poor person, so ... but they should all get treated the same. But between rich and poor, some people choose to be poor.

3.19 Notice that Emile and Bob reject the idea that rich and poor really are the same. At the very least, they suggest, rich and poor have made different choices. But even though they think people (deservedly) enjoy different lifestyles because they have made different choices, they still want everyone to be treated 'as equals'. Almost all of the groups ruled out any gloating and boasting about possessions because 'we are all the same' but at the same time accepted that most material inequality was the fair consequence of differences in effort.

3.20 The way in which the two interpretations coexisted is also illustrated by some of the proposals that young people made in relation to economic inequality, namely: to stop rich and poor mixing, to reduce discussion of economic inequality and psychological support to minimize feelings of jealousy. These proposals tended to draw on egalitarian ideas and sought to minimise different treatment of people because of economic inequality, but did not tend to challenge the existence of that inequality. I will briefly examine each in turn.

\section{Separation of rich and poor}

3.21 Participants suggested that the rich and poor shouldn't mix. Several groups saw private schools as an acceptable and desirable way of keeping the rich and poor separate. Spud (14 year old boy, Pilot School) said matter-of-factly, 'Private school you have to pay to get in, so it's more for richer parents, for them to get their children a good education.' The other members of his focus group agreed that this arrangement prevented the bullying of richer or poorer students. Some advocated greater separation of rich and poor children in schools to prevent interpersonal conflict:

Pavvi Because if the parents are rich, they shouldn't send you to a much richer school, like instead of a school that is not that rich, because then people might like say, oh, treat you -

Boy You feel dumb.

Boy Yeah.

Pavvi Yeah, you feel down basically because the teacher aint treating you the same as they are treating them. ... Or if you are going to send your child to a school like that, keep it a secret that you are rich or something.

Lampard Don't go bragging about it. (11 year old boys, Secondary Modern School)

3.22 Note how in this quotation these boys feel it is right for a rich child to go to a 'richer school'. Poppy (14 year old girl, Independent School) supported this, saying, 'The idea is with most schools, like you want the same kind of people in it.' Humphrey (11 year old boy, Independent School) echoed this sentiment when he said that rich people would avoid poor people:

Humphrey It's like, if you are really posh and you are really wealthy, and then there's poor people who are a bit, 'you all right mate', like, they wouldn't really mix with those sort of people.

3.23 These proposals seek for people to be in more segregated communities to prevent the difficult feelings or conflict that might arise when rich and poor meet and ensure that people feel that they are all the same. Work by Runciman (1966) and Pahl et al. (2007) suggests that this strategy might reduce social antagonism, as the narrower the reference group used to compare wealth, the less resentment expressed. However, while this proposal draws on the egalitarian idea that people should feel they are the same, it does so in a way that does not challenge the existence of economic inequality, or the belief that people are individually responsible for their income or wealth. 
3.24 Participants also suggested that material inequality should be spoken about less often. They were particularly keen that richer children should keep quiet about their possessions, and not gloat. Bart (11 year old boy, Pilot School) said, 'You shouldn't be boasting to the lower class people or the people poorer than you saying "look what I got" and I shop from this shop and you don't shop from that shop and stuff like that,' and Grace (11 year old girl, Catholic School) commented that rich people shouldn't be 'posh and boastful about how much money they have'. Pavvi (11 year old boy, Secondary Modern School) suggested that schools should teach pupils not to show off about things:

\begin{abstract}
Pavvi I think we should learn about stuff like that, because every time someone gets something new, they always show off about it and the people who can't afford it, they get really jealous and will start asking their parents for it, and their parents really can't afford it. So they need to let them know what they are doing wrong and stop showing off their things. (11 year old, Secondary Modern School)
\end{abstract}

3.25 Pupils did not only want to reduce boastful talk, but any discussions about rich and poor. Almost all of the groups were uncomfortable talking about economic inequality (unless it involved complaining about the boasting of others). Even a group of 11 year old boys at the Comprehensive School that spoke movingly and at length about their frustration at not having 'the right brands' told me that differences between rich and poor were not 'really exciting to talk about or fascinating' and so weren't 'something [11 year olds] really like to speak about'. Emile and Shaun, 14 year old boys also at the Comprehensive School, told me that 'People find it easier not to talk about it,' and 'It doesn't really affect us, so we don't really have much to say about it'. Thus participants suggested that all talk of rich and poor should be reduced because those discussions made people 'feel rubbish inside, like they're not very good'.

3.26 These suggestions seem to draw implicitly on the egalitarian idea that everyone is the same, and should not be made to feel less important, contradicting the neo-liberal notion that people deserve what they have and can therefore show it off. The proposal would make it easier to believe 'everyone is the same' because material inequality is not be discussed. However, at the same time, it makes the egalitarian challenge to the existence and extent of economic inequality less obvious.

\title{
Dealing with feelings through therapy
}

3.27 Somewhat paradoxically, a third proposal for dealing with situations of material inequality was for more discussion of the topic, but in a therapeutic setting such as counselling. A group of 11 year old boys at the Comprehensive School said that they would deal with the emotions they experienced when others 'flashed' their better clothes through the 'resilience' lessons they received as part of PSHE (personal, social and health education). These lessons were part of a cognitive behavioural programme designed to help students to 'develop more accurate thinking through emotional awareness, problemsolving, assertiveness, peer relationship skills and decision making techniques' (from programme website). The boys said that they had learnt if they still felt upset or angry about people having more than them and trying to 'flash it' then they should visit a counsellor. In another school, a group of 11 year old girls explained that one way to deal with issues of unfairness was for them to talk confidentially to older students as part of a peer counselling scheme. Two other groups of girls proposed that people should learn self-respect, self-esteem or to have pride in themselves as a solution to interpersonal conflict over inequality.

3.28 In claiming that everyone should respect each other and have high self-esteem, these pupils are drawing on the egalitarian philosophy that 'everyone is the same'. Recognising that this is not the case in situations of material inequality, they have turned to the talking therapies of the 'psy' disciplines (psychology, psychotherapy etc) for help. It could be that counselling about situations of material inequality might cause young people to see feelings about material inequality as sociological, political and ethical issues. However, Rose (1996) argues that these techniques often focus on adjustment to the neo-liberal norm, because the techniques for the individual to use in taking responsibility and improving their motivation/productivity/attitude are very closely aligned with neo-liberal ideology that requires individuals to take responsibility and engineer their own economic destiny. Thus although the proposal to handle situations of material inequality through therapy draws to some extent on egalitarian principles, it does so in a way that enables continued support of neo-liberal ideologies.

\section{Conclusions}

4.1 In this paper I have shown that participants spoke about economic inequality in terms of rich and poor, but tended to place themselves in the middle of the income distribution. Despite this selfplacement, they often felt very strongly about experiences where economic inequality was visible through consumption patterns (especially of branded clothing or consumer electronics). Situations where they had fewer/less good consumer goods than others were associated with strong feelings of discomfort, inferiority and jealousy, while situations where others had less were associated with a mixture of discomfort, guilt and indifference. Participants used ideas of neo-liberal meritocracy to explain that the existence of economic inequality was the fair result of different skills or effort among the rich and the poor. But at the same time they claimed that that rich and poor were the 'same kind of people' and that luck played a great part in the different levels of wealth and possessions. This second appraisal of economic inequality led to them argue that everyone should be treated the same and granted the same respect, regardless of whether they were rich or poor. While this more egalitarian interpretation of economic inequality potentially challenges some of the assumptions at the heart of neo-liberal ideology, this conflict was not acknowledged. Rather, egalitarian sentiments were drawn on to propose strategies to 
minimise situations where rich and poor might be treated differently, or to manage the difficult feelings and lack of respect that participants associated with situations of economic inequality. These proposals did not challenge the existence of economic inequality, but focussed on the justice of how people with different levels of wealth or possessions should be treated.

4.2 These findings suggest that neo-liberal explanations for economic inequality are important in the way these young people understand the world around them, providing an explanation that makes sense and appeals to the young people, especially given their understanding of their own place in the middle of the income distribution. Some psychologists argue that this is because the belief that the world is just and individuals are in control of their fate is an important psychological coping strategy (Furnham 2003). People therefore have a bias to interpret everyday events in this way. Sociologists argue that the rich promulgate neo-liberal ideologies because they sustain and legitimise their powerful positions, and the ideology becomes part of the taken-for-granted common sense of everyone, including the poorest (Bourdieu 1990; Fairclough 2001). Whatever the reason, these ideologies are being used by young people to help understand the world around them. However, neo-liberal explanations of economic inequality are not hegemonic, and most young people also subscribe to some degree of egalitarian interpretation. But, significantly, these explanations tend to lead to proposals to minimise the appearance or visibility of economic inequality, rather than to direct challenges of the existence of that inequality. This seems likely to perpetuate young people's perception that they are in the middle of the income distribution, and to result in the continuation or even growth of current levels of economic inequality.

4.3 The importance that these young people place upon respect and being treated well chime with some of the writing of Fraser (2005), Sayer (2005) and Young (1990) who write about the interpersonal and cultural dimensions of social justice in addition to the economic aspect. There are echoes here of Fraser's (1997) claim that the institutionalized hierarchies of cultural value cannot be reduced to a secondary effect of economic mal-distribution. These young people would seem to agree with those theorists who argue that social justice is more than economic justice, and they are very concerned about the cultural and interpersonal unfairness they believe arises from the disrespect some feel or witness when they lack consumer goods. However, by using neo-liberal ideas to think about economic distribution and egalitarian ones to talk about the treatment of people with different levels of wealth and possessions they tend to deny or obscure any connection between the two issues. This is in contrast with Sayer (2005) who suggests that cultural recognition and respect always has a basis in goods, because in order to live in ways that are deserving of recognition people need conditions that support those ways of living. In contrast with the approach of these young people, Sayer (ibid) argues that the respect and recognition in discourse and attitudes is important, but is likely to be tokenistic (and perhaps unachievable) if not accompanied by material actions.

4.4 These findings further suggest that one reason for the continued use of both neo-liberal and egalitarian interpretations of economic inequality is the relative dearth of opportunities for young people to engage in ideological discussions about ideas of social justice. Participants only described talking about material inequality with their friends, and sometimes in peer counselling or PSHE (personal, social and health education). In these situations, the emphasis was on managing feelings. While this was something participants found useful, it does not help them evaluate and clarify their own value position. Given their strong feelings about situations where economic inequality is evident in consumption, young people might find discussion of these kinds of situations an engaging way into consideration of the underlying principles and philosophies. This would give them an opportunity to consider the ideological conflict between the neo-liberal and egalitarian ideas with which they are familiar, and also a chance to think about other theories of social justice (e.g. Gewirtz 1998) to which they made very little reference.

\section{References}

AHIER, J. and J. Beck (2003) 'Education and the Politics of Envy'. British Journal of Educational Studies, Vol. 51, No. 4, pp. 320 - 43. [doi:10.1046/j.1467-8527.2003.00242.x]

APPLE, M. W. (2001) 'Comparing Neo-liberal Projects and Inequality in Education'. Comparative Education, Vol. 37, No. 4, pp. 409 - 23. [doi:10.1080/03050060120091229]

APPLE, M. W. and J. Beane (1995) Democratic Schools. Association for Supervision and Curriculum Development.

ARCHER, L., S. Hollingworth, and A. Halsall (2007) 'University's not for Me - I'm a Nike Person': Urban, Working-Class Young People's Negotiations of 'Style', Identity and Educational Engagement'. Sociology, Vol. 41, No. 2, pp. 219 - 237 [doi:10.1177/0038038507074798]

ARCHER, M. S. (2007) Being human: the problem of agency. Cambridge: Cambridge University Press.

ATTREE, P. (2004) 'Growing up in disadvantage: a systematic review of the qualitative evidence'. Child: Care, Health and Development, Vol. 30, No. 6 pp. 679-89. [doi:10.1111/j.1365-2214.2004.00480.x]

AVERY, P.G. (1988) 'Policy Thought among Children and Adolescents: A Review of the Literature. Monograph No. 3.' Journal of Social Studies Research, Vol. 12, No. 2.

BALL, S. (2003) 'Social Justice in the Head: are we all libertarians now?', in C Vincent (ed.), Social Justice, Education and Identity London: RoutledgeFalmer. [doi:10.4324/9780203464106]

BAMFIELD, L. and T. Horton (2009) Understanding attitudes to tacking economic inequality. York: Joseph 
Rowntree Foundation.

BAUMAN, Z. (1998) Work, consumerism and the new poor. Buckingham: Open University Press.

BAUMAN, Z. (1999) In Search of Politics. Stamford University Press.

BOURDIEU, P. (1990) The logic of practice Cambridge: Polity.

CLARKE, J. and J. Newman (1997) The managerial state: power, politics and ideology in the remaking of social welfare. London: Sage.

CLARKE, J. (2004) 'Dissolving the Public Realm? The Logics and Limits of Neo-liberalism', Journal of Social Policy, Vol. 33, No. 01 pp. 27-48. [doi:10.1017/S0047279403007244]

CROGHAN, R., C. Griffin, J. Hunter and A. Poenix. (2006) 'Style Failure: Consumption, Identity and Social Exclusion', Journal of Youth Studies, Vol. 9, No. 4 pp. 463-78. [doi:10.1080/13676260600914481]

DITTMAR, H. (1994) 'Material possessions as stereotypes: Material images of different socio-economic groups', Journal of Economic Psychology, Vol 15. No. 4 pp. 561-85. [doi:10.1016/0167-4870(94)90011-6]

FAIRCLOUGH, N. (2001) Language and Power (Second Edition) Harlow: Pearson Education.

FRASER, N. (1997) Justice interruptus: critical reflections on the "postsocialist" condition. London: Routledge.

FRASER, N. (2005) 'Reframing Justice in a Globalizing World', New Left Review Vol. 36, pp 69 - 89.

FURNHAM, A. (2003) 'Belief in a just world: research progress over the past decade', Personality and Individual Differences, Vol. 34 pp. 795-817. [doi:10.1016/S0191-8869(02)00072-7]

GEWIRTZ, S. (1998) 'Conceptualizing social justice in education: mapping the territory', Journal of Education Policy, Vol. 13, No. 4 pp. 469 - 84. [doi:10.1080/0268093980130402]

GIDDENS, A. (1991) Modernity and self identity : self and society in the late modern age. Cambridge: Polity Press in association with Basil Blackwell.

GORARD, S. (2011) 'The potential determinants of young people's sense of justice: an international study, 'British Journal of Sociology of Education, Vol. 32, pp 35-52. [doi:10.1080/01425692.2011.527721]

HARRIS, S. (2006) 'Social Constructionism and Social Inequality: An Introduction to a Special Issue of JCE', Journal of Contemporary Ethnocgraphy, Vol 35, pp 223 - 235. [doi:10.1177/0891241606286816]

HARVEY, D. (2005) A brief history of neoliberalism. Oxford: Oxford University Press

HILLS, J (ed.) (1996) New Inequalities: the changing distribution of income and wealth in the UK. Cambridge: Cambridge University Press

HILLS, J., M. Brewer, S. Jenkins, R. Lister, R. Lupton, S. Machin, C. Mills, T. Modood, T. Rees and S. Riddell (2010) An Anatomy of Economic Inequality in the UK. London: Government Equalities Office/Centre for the Analysis of Social Exclusion.

HOLLAND, J. and R. Thompson (1999) ESRC End of Award Report Youth Values: identity, diversity and social change (Award no. L129251020). ESRC.

HOLLINGWORTH, S. 'Social and educational inequalities in English state schools: exploring the understandings of urban white middle class children ', in L. Holt (ed.), Geographies of Children Youth, and Families (Routledge, 2010).

KLEUGEL, J. R. and E. R. Smith (1986) Beliefs About Inequality: Americans' Views of What Is and What Ought To Be. New York: Aldine De Grutyer.

KOHLBERG, L. (1983) Moral stages: a current formulation and a response to critics. London: Karger.

ORTON, M. and K. Rowlingson (2007) 'Public Attitudes to Economic Inequality'. York: Joseph Rowntree Foundation.

PAHL, R., D. Rose and L. Spencer (2007) "Inequality and Quiescence: A Continuing Conundrum." Colchester: University of Essex.

RAWLS, K. (1971) A theory of justice Cambridge, Mass: Harvard University Press, 1971

REAY, D., G. Crozier, D. James, S. Hollingworth, K. Williams ,F. Jamieson and P. Beedell (2007) Identities, Educational Choice and the White Urban Middle-Classes: Full Research Report. ESRC End of Award Report. Swindon: ESRC.

RIDGE, T. (2002) Childhood Poverty and Social Exclusion: from a Child's perspective. Bristol: Policy Press. 
RIDGE, T. (2009) 'Living with poverty: A review of the literature of children's and families' experiences of poverty'. London: DWP.

RILEY, S. and C. Griffin (2007) Reverberating Rhythms: Social Identity \& Political Participation in Clubland: Full Research Report. ESRC End of Award Report. Swindon: ESRC.

ROBSON, C. (1993) Real world research : a resource for social scientists and practitioner-researchers Oxford: Blackwell, 1993

ROSE, N. S. (1996) Inventing our selves: psychology, power, and personhood. Cambridge: Cambridge University Press. [doi:10.1017/CBO9780511752179]

RUNCIMAN, W. G. (1966) Relative deprivation and social justice. London: Routledge and Keegan Paul. SANDEL, M. J. (2009) Justice: What's the right thing to do? Allen Lane

SAUNDERS, P. (2006) Meritocracy and Popular Legitimacy. The Political Quarterly, Vol. 77, pp 183-94. [doi:10.1111/j.1467-923X.2006.00794.x]

SAYER, R. A. (2005) The Moral Significance of Class. Cambridge: Cambridge University Press [doi:10.1017/CBO9780511488863]

SHELDON, R., R. PLATT and N. Jones (2009) Political debate about economic inequality. York: Joseph Rowntree Foundation.

STAKE, R. E. (1995) The art of case study research : perspectives on practice London: Sage

TOYNBEE, P. and D. Walker (2008) Unjust Rewards: Exposing Greed and Inequality in Britain Today Granta Books.

YOUNG, I. M. (1990) Justice and the politics of difference. Princeton: Princeton University Press. 